\title{
Research Artick: Combining ability analysis for yield and related traits in rice (Oryza sativa L.)
}

\author{
N. SANDHYAKISHORE, G. PRAVEENKUMAR, M. PALlAVI, \\ J. KAMALAKAR, F. SHAHANA AND K.R. TAGORE
}

Article Chronicle: Received : 17.07.2017;

Accepted :

01.08.2017

Key Words :

Rice, Line x Tester,

Combining ability

Author for correspondence :

\section{N.}

SANDHYAKISHORE

Regional Sugarcane and Rice Research Station, Rudrur, NIZAMABAD (TELANGANA) INDIA

Email: kishoregene

@gmail.com
SUMMARY : Study of combining ability was conducted on $12 \mathrm{~F}_{1}$ hybrids along with seven rice genotypes to know the pattern of inheritance of some morphological traits for selecting superior genotypes. The experiment was carried out and crossing programme initiated in line $\mathrm{x}$ tester mating design during Post rainy season 2013-14 and subsequently hybrids along parents were evaluated during rainy season 2014. Analysis of variance for combining ability revealed highly significant mean square for all the characters due to interaction between parents vs. crosses indicating wide difference among hybrids. The greater magnitude of SCA variance then GCA variance indicated the role of non additive gene action. RDR-884 identified as good general combiner for grain yield as well as other desirable traits like earliness, panicle length, 1000 grain weight. While the cross combinations viz., JGL$11470 \times$ JGL-3844 and JGL-1798 x WGL-283 with good per se performance and significant SCA effect for yield and yield components may be exploited by involving them multiple cross breeding programme for obtaining transgressive segregants and broad genetic base population in rice yield improvement.

How to cite this article : Sandhyakishore, N., Praveenkumar, G., Pallavi, M., Kamalakar, J., Shahana, F. and Tagore, K.R. (2017). Effect of different organic manures, inorganic fertilizers and growth regulator on yield attributes and yield of greengram (Vigna radiata L.). Agric. Update, 12(TECHSEAR-6) : 1573-1577; DOI: 10. 15740/HAS/AU/12. TECHSEAR(6)2017/1573-1577. 